\title{
Genotype association GSTM1 null and gastric cancer: evidence-based meta-analysis
}

\author{
Rívian Xavier RIBEIRO, Cícera Isabella Leão Leite NASCIMENTO and \\ Antonio Márcio Teodoro Cordeiro SILVA
}

ABSTRACT - Background - Gastric cancer is the fourth most common cancer in men and the sixth among women, except for non-melanoma skin tumors, in Brazil. Epidemiological evidences reveal the multifactorial etiology of this cancer, highlighting risk factors such as: infection by the bacterium Helicobacter pylori, advanced age, smoking, chronic alcohol abuse, eating habits and genetic polymorphisms. Considering the context of genetic polymorphisms, there is the absence of the GSTM1 gene. The lack of GSTM1 function to detoxify xenobiotics and promote defense against oxidative stress leads to increased DNA damage, promoting gastric carcinogenesis. This process is multifactorial and the development of gastric cancer results from a complex interaction of these variables. Objective - The aim of this study was to investigate the association of GSTM1 null polymorphism in the pathogenesis of gastric cancer. Methods - A meta-analysis was conducted from 70 articles collected in SciELO and PubMed databases, between September 2015 and July 2016. In order to evaluate a possible association, we used the odds ratio (OR) and confidence interval of $95 \%$ (CI $95 \%$ ). To assess the heterogeneity of the studies was used the chi-square test. Statistical analysis was performed using the BioEstat ${ }^{\circledR} 5.3$. Results - This study included 70 studies of case-control, including 28,549 individuals, which were assessed for the null polymorphism of the GSTM1 gene, and of which $11,208(39.26 \%)$ were cases and 17,341 (60.74\%) were controls. The final analysis showed that the presence of the GSTM1 gene acts as a protective factor against the development of gastric cancer $(\mathrm{OR}=0.788 ; 95 \% \mathrm{CI} 0.725-0.857 ; P<0.0001)$. Positive statistical association was found in Asia $(\mathrm{OR}=0.736$; 95\% CI 0.670-0.809; $P<0.0001)$ and Eurasia $(\mathrm{OR}=0.671 ; 95 \% \mathrm{CI} 0.456-0.988 ; P=0.05)$. However, statistically significant data was not obtained in Europe $(\mathrm{OR}=1.033 ; 95 \% \mathrm{CI} 0.873-1.222 ; P=0.705)$ and America $(\mathrm{OR}=0.866 ; 95 \% \mathrm{CI} 0.549-1.364 ; P=0.534)$. Therefore, the results can not be deduced around the world. Conclusion - This meta-analysis concluded that the presence of the GSTM1 gene is a protector for the emergence of gastric cancer, especially in Asian countries, but this result was not found in Europe and America.

HEADINGS - Stomach neoplasms. Genetic polymorphism. Meta-analysis.

\section{INTRODUCTION}

Malignant tumors of the stomach are present predominantly in the form of three histologic types: adenocarcinoma accounts for $95 \%$ of the tumors; lymphoma, diagnosed in about $3 \%$ of cases; and leiomyosarcoma, initiated in tissues that give rise to the muscles and bones ${ }^{(74)}$.

In Brazil, gastric cancer is the fourth most common cancer in men and the sixth among women, except for nonmelanoma skin tumors $^{(74)}$. In the rest of the world, according to the International Agency for Research on Cancer (GLOBOCAN), gastric cancer is the fourth most common cancer in men and the fifth in women ${ }^{(17)}$. More than $70 \%$ of gastric cancer cases occur in developing countries. The incidence rate of this disease is two times higher in males than in females. The peak incidence occurs mostly in men, around 70 years old. About $65 \%$ of patients diagnosed with this cancer are over 50 years old ${ }^{(17,74)}$.

The highest mortality rates are recorded in Latin America, especially Costa Rica, Chile and Colombia. However, the greatest number of cases occurs in Japan, where they found 780 patients per 100,000 inhabitants. Gastric cancer does not have a good prognosis, and mortality remains high throughout the world ${ }^{(74)}$.
A study conducted by the National Cancer Institute José Alencar Gomes da Silva (INCA), demonstrated that the median survival of gastric cancer after surgical resection was 15 months (0-65 months), with higher survival rates for stage I and II and lower survival for stage III and IV ${ }^{(11)}$. European data shows that only $21 \%$ of patients survive more than five years after diagnosis ${ }^{(7)}$. And therefore, in Brazil and in the world, it is a major public health problem.

The process of carcinogenesis is multifactorial and not completely understood. In addition to nutritional and behavioral factors, genetic characteristics have shown to be increasingly important. The development of gastric cancer results from a complex interaction of these variables ${ }^{(68,86,89)}$. Genetic susceptibility may modify the effect of environmental exposure, thus explaining the variations in incidence of cancer around the world ${ }^{(23,34)}$.

The individuality of genetic susceptibility is critical in the various factors that influence carcinogenesis, such as: protection of the gastric mucosa in the face of infection by Helicobacter pylori; inflammatory response to the infection; capacity of detoxification and antioxidant protective action; cell proliferation capacity; variability in the DNA repair process; apoptotic pathway ${ }^{(15,49,80,92)}$.

In addition, part of the susceptibility is determined by indi- 
vidual differences in bioactivation of proto-oncogenes and detoxification of carcinogens due to metabolism and degree of penetrance of inherited polymorphisms ${ }^{(34,49)}$.

Several genes with low penetrance were identified as potential carcinogens. Glutathione S-transferase (GST) is a superfamily of homo- and hetero-dimeric enzymes that catalyze the conjugation of potential carcinogens in glutathione, playing an important role in protecting cell structures, including DNA ${ }^{(89)}$.

In humans, eight distinct $G S T$ genes were found, among them five are widely distributed: alpha (GSTA), sigma $(G S T S), \mathrm{mi}$ $(G S T M)$, pi $(G S T P)$ and theta $(G S T T)^{(9,49)}$. Located on chromosome 1p13.3, the GSTM1 plays an important role in detoxification of xenobiotics ${ }^{(89)}$. Among the isoforms in the GST, the GSTMI has a particular function, because the null polymorphism results from the total absence of the enzyme produced by $\mathrm{it}^{(80)}$.

The most common GSTM1 polymorphism gene is a homozygous deletion (null), which has been associated with reduced enzyme activity and increased vulnerability to cytogenetic damage ${ }^{(89)}$. The $G S T$ enzymes commonly act on environmental pollutants, such as benzopyrene and other polycyclic aromatic hydrocarbons, which are important carcinogens. Lack of GSTM1 function to detoxify xenobiotics and promote defense against oxidative stress leads to increased DNA damage, promoting gastric carcinogenesis ${ }^{(61)}$.

The association between GSTM1 null genotype and gastric cancer was first described by Strange in 1991 in the British population. In recent years, several studies have attempted to demonstrate a positive association between GSTM1 null and gastric cancer. However, the results have been conflicting regarding this association ${ }^{(80,89)}$

Considering both genders, gastric cancer is the fifth most frequent cancer and third leading cause of cancer death worldwide. Proper management of this disease is a major public health problem, both nationally and internationally. Knowledge of the interactions and molecular changes involving the carcinogenic process can lead to a way for the control of gastric cancer. In this perspective, the genetic role of polymorphisms has acquired a lot of relevance in the scientific community ${ }^{(80)}$. Given this universal scenario, the aim of this study is to investigate the association of GSTM1 null polymorphism in the genesis of gastric cancer and compare the different effects of this association in Asia, America, Europe and Eurasia.

\section{METHODS}

The meta-analysis is a research technique that selects and extracts studies results through strict procedures. The results are then summarized by statistical analysis in order to reduce the subjectivity of the traditional methods of narrative review. Thus, combining results from different primary studies and their use in recent years, added significantly to the area of health by the high degree of recommendation associated with levels of evidence that it translates ${ }^{(63,67)}$.

The main steps of a meta-analysis are: (1) the literature, (2) the transformation of the results of each study group on a common measure, (3) checking the homogeneity of the results, (4) modeling variation between studies, and finally (5) the sensitivity analysis ${ }^{(20)}$.

\section{Search and retrieval studies}

The research of articles was conducted from databases of Scientific Electronic Library Online (SciELO) and PubMed National Center for Biotechnology Information, USA (NCBI), between
September 2015 and July 2016, for the extraction of relevant studies that estimated the association between GSTM1 polymorphism and the risk of gastric cancer. For this, the following keywords were selected: "GSTM1", "gastric cancer", "Glutathione S-transferase M1", and "Meta-analysis". During the research, articles in Portuguese, English and Spanish were selected. Limitations were not made regarding the size of the sample obtained by surveyed items.

\section{Inclusion and exclusion criteria}

In the context of meta-analysis, it is important to assess the heterogeneity, as it consists in the variability or differences between studies in relation to the estimating effects and therefore its identification is critical to assess the degree of confidence in the results. Overall, the authors divide the heterogeneity into three types: clinical, methodological or statistical ${ }^{(58,73)}$. In order to minimize these parameters, the inclusion criteria are defined: (1) Case-control studies; (2) histologic confirmation of adenocarcinoma; (3) gene by PCR Research GSTM1; (4) articles published from 1990 to 2015; (5) articles in languages: English, Portuguese and Spanish; (6) articles fully accessed by researchers.

\section{Data extraction}

The extraction of relevant data were made by two researchers independently, discrepancies in data collection were discussed and a consensus was reached among researchers. Data taken from the table were: year of publication of the article, lead author, country, continent, number of cases and controls and presence of polymorphisms of GSTMI in cases and controls.

\section{Statistical analysis}

Heterogeneity is defined as the diversity of the studies and can strongly affect the results. The diversity can then be evaluated for heterogeneity $\chi^{2}$ test ${ }^{(58,73)}$. Thus, the genotypic frequencies of all articles were grouped into a single table and diversity was assessed with the use of heterogeneous $\chi^{2}$ test in $2 \times 2$ contingency tables, to compare the different odds ratios (OR) with a confidence interval of $95 \%$, determined in their studies.

If the heterogeneity of the $\chi^{2}$ test reveals a $P>0.05$, the null hypothesis is confirmed, i.e., the studies are homogeneous. So it is recommended to use the fixed-effect tests that assume that all studies point in the same direction. In this context, the most used is the Mantel-Haenszel test. On the other hand, if the heterogeneity $\chi^{2}$ test results in a $P<0.05$, it indicates diversity and heterogeneity between studies. Therefore, the use of random or random effect tests is recommended, such as the DerSimonian-Laird tests ${ }^{(4,6,26,91)}$.

Global association tests were then used to assess the significance of the correlation between the polymorphism of gene GSTM1 and gastric cancer for all studies combined. To estimate the effect of gene polymorphism in the development of gastric cancer, the amounts of each study were combined with fixed and random tests of effects utilizing the software BioEstat ${ }^{\circledR} 5.3^{(26)}$. Either for fixedeffect tests or for the random effects, odds ratios are calculated, its confidence intervals $(95 \%)$ and the weights for each individual and combined study, generating an estimated combined effect. In addition, the tests elaborate a graphical forest plot type. The advantage of these charts is to summarize, in the same space, all the information on the effect and the contribution of each study for analysis ${ }^{(73)}$.

As the grouping of all studies showed heterogeneity, we applied the random effects test DerSimonian-Laird for all genotypic 
possibilities: the presence or absence of the GSTM1. This same grouping strategy was used to stratify studies by more frequent locations: Asia (50 studies), Europe (12 studies), America (5 studies) and Eurasia (3 studies). For groupings with the presence of gastric cancer realized in Asia, America and Europe, they utilized the DerSimonian-Laird test. On the other hand, for the variables of the locations in Eurasia, the fixed effect Mantel-Haenszel test was applied.

\section{RESULTS}

In this meta-analysis, after researching databases, we selected 174 articles on the polymorphism of the GSTM1 gene, published between the years 1991 to 2015. Of these articles, 104 articles were discarded for not meeting the inclusion criteria (Figure 1). Thus, 70 articles were brought together that evaluated the association of GSTM1 polymorphism and gastric cancer.

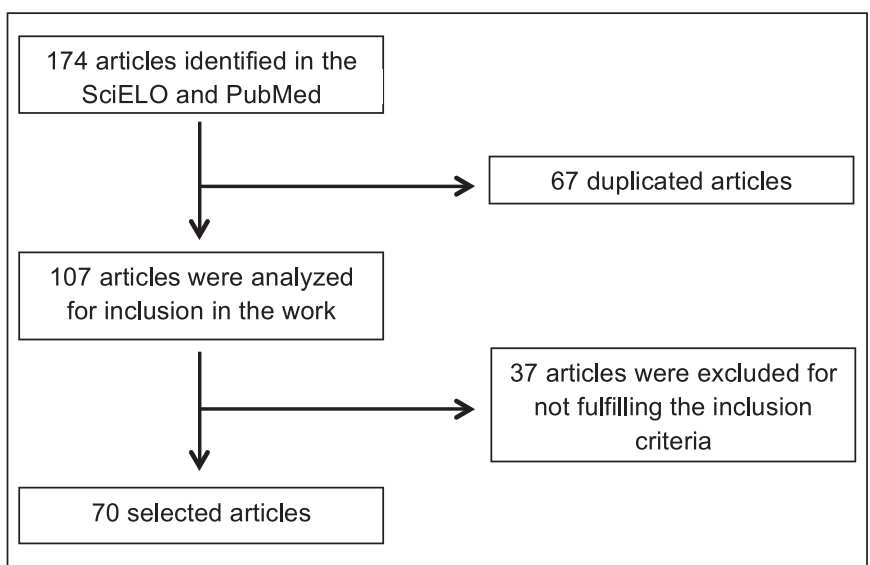

FIGURE 1. Identification of criteria, inclusion and exclusion, of the meta-analysis studies.

Among the articles selected, 50 were made in Asia, 12 in Europe, 5 in the Americas (North, Central and South) and 3 in Eurasia. This study included 28,549 individuals assessed for polymorphism of the GSTM1 gene, of which 11,208 (39.26\%) were part of the group of cases diagnosed with gastric cancer, and 17,341 (60.74\%) were part of the control group. For comparison purposes, to group the data, the frequency of the presence of the GSTM1 gene in cases and controls were, respectively, $46.0 \%$ and $50.4 \%$.

The data of the GSTM1 polymorphism of the gene were grouped into each article. Thus, the odds ratios (OR) were calculated for each study, their variations within the $95 \%$ confidence interval and significance probabilities $(P)$.

For each cluster, we applied the DerSimonian-Laird test, except for the grouping in Eurasia, where we used the Mantel-Haenszel. The odds ratios were calculated with the grouping of all studies for: America $(\mathrm{OR}=0.866 ; 95 \% \mathrm{CI} 0.549-1.364 ; P=0.534$; Figure 2$)$, Eurasia $(\mathrm{OR}=0.671 ; 95 \%$ CI $0.456-0.988 ; P=0.05$; Figure 3$)$, Europe $(\mathrm{OR}=1.033 ; 95 \% \mathrm{CI} 0.873-1.222 ; P=0.705$; Figure 4$)$ and Asia $(\mathrm{OR}=0.736 ; 95 \% \mathrm{CI} 0.670-0.809 ; P<0.0001)$.

The graphics generated in the meta-analysis are the forest plot type. This type of chart, each line represents one study, with the latter, in the shape of a rhombus, represents the combined results. The result of each study is described in graphical and numerical forms. In graphic form, the central squares represent the relative risk

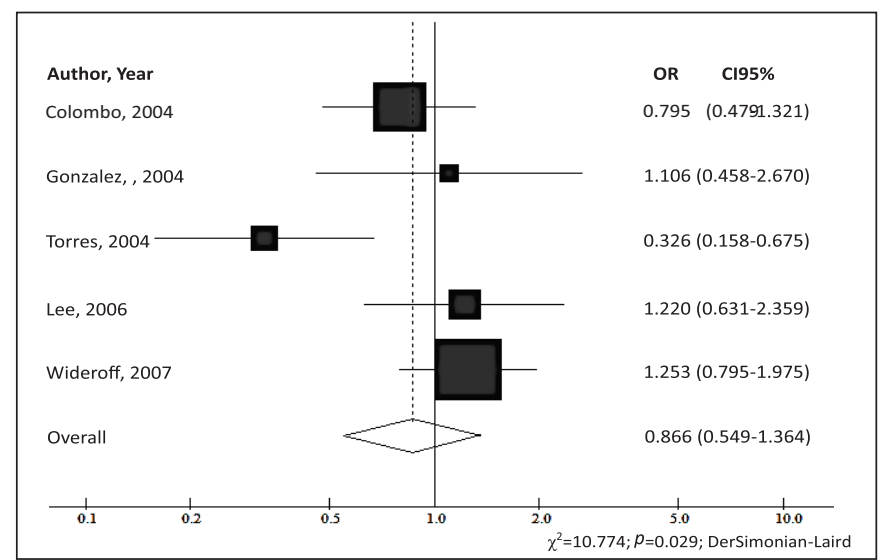

FIGURE 2. Odds ratios (OR) and confidence interval of $95 \%(95 \% \mathrm{CI})$ of the association between gastric cancer and the presence of GSTM1 for the studies carried out in America with the Chi-square test of significant heterogeneity (DerSimonian-Laird test).

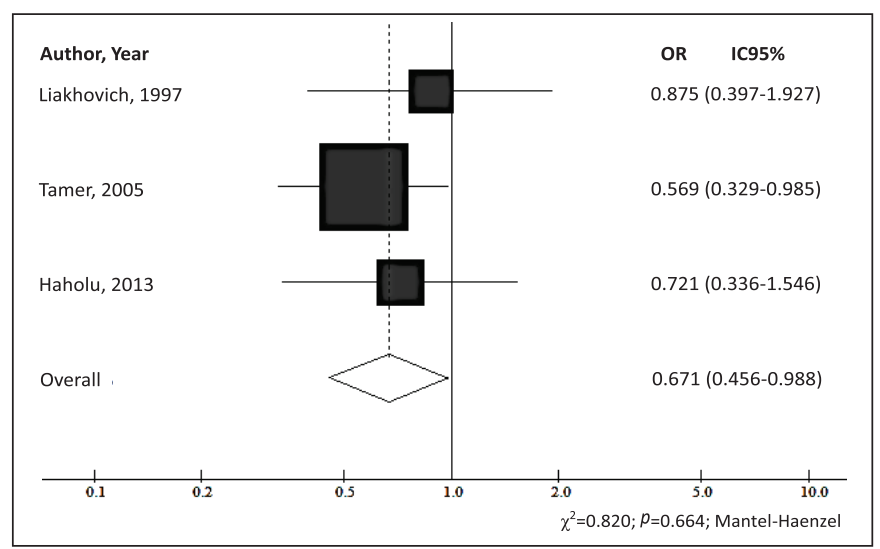

FIGURE 3. Odds ratios (OR) and confidence interval of 95\% (95\% CI) of the association between gastric cancer and the presence of GSTM1 for the studies carried out in Eurásia with the Chi-square test of significant heterogeneity (Mantel-Haenzel test).

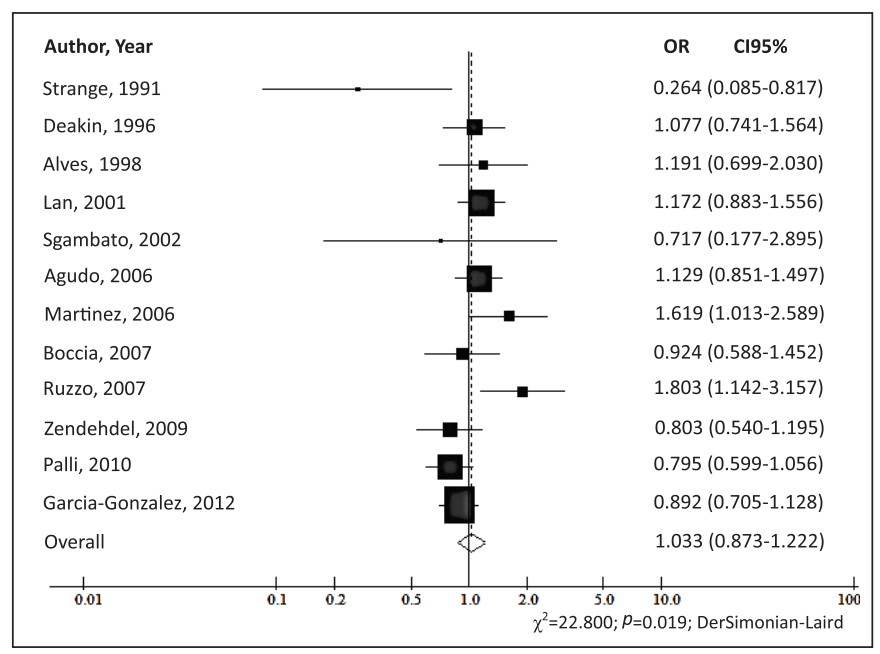

FIGURE 4. Odds ratios (OR) and confidence interval of $95 \%(95 \% \mathrm{CI})$ of the association between gastric cancer and the presence of GSTM1 for the studies carried out in Europa with the Chi-square test of significant heterogeneity (DerSimonian-Laird test). 
(RR) or odds ratio and the traits represent the confidence intervals (CI). When the CI does not exceed the null line (position 1.0 in the chart), it can be said that the study is statistically significant, both individually and for the combined value. The larger the sample group considered in the study, narrower will be the CIs and greater will be the area of the square, showing more accurate results and greater contribution to the meta-analysis.
Additionally, information on the polymorphism of gene GSTM1 were grouped into each article, we calculated the OR, the variation of OR within the $95 \%$ confidence interval and the probability of significance $(P)$ (Table 1$)$. When applying DerSimonianLaird test, the OR of all the combined work $(\mathrm{OR}=0.788 ; 95 \% \mathrm{CI}$ $0.725-0.857 ; P<0.0001)$ showed that the presence of the gene is a protective factor for gastric cancer.

TABLE 1. Distribution of the polymorphism of the GSTM1 gene in patients with gastric cancer, in the case and control groups in the published articles between 1991 and 2015 and the database of the current study

\begin{tabular}{|c|c|c|c|c|c|c|c|c|c|c|c|c|c|}
\hline \multirow{3}{*}{ Author } & \multirow{3}{*}{ Year } & \multicolumn{4}{|c|}{ Case } & \multicolumn{4}{|c|}{ Control } & \multirow{3}{*}{ OR } & $\mathrm{CI}$ & $\%)$ & \\
\hline & & GS7 & $1(+)$ & $G S$ & $1(-)$ & GSI & $(+)$ & $G S$ & $(-)$ & & Inf & Sup. & Weight \\
\hline & & $\mathrm{n}$ & $\mathbf{F}(\%)$ & $\mathrm{n}$ & $\mathrm{F}(\%)$ & $\mathrm{n}$ & $\mathrm{F}(\%)$ & $\mathrm{n}$ & $\mathrm{F}(\%)$ & & Inf. & sup. & \\
\hline Strange $e^{(75)}$ & 1991 & 5 & 26.3 & 14 & 73.7 & 29 & 59.2 & 20 & 40.8 & 0.264 & 0.085 & 0.817 & 2.999 \\
\hline Harada ${ }^{(25)}$ & 1992 & 5 & 26.3 & 14 & 73.7 & 44 & 52.4 & 40 & 47.6 & 0.175 & 0.057 & 0.531 & 3.105 \\
\hline Kato $^{(31)}$ & 1996 & 34 & 53.1 & 30 & 46.9 & 59 & 49.2 & 61 & 50.8 & 1.169 & 0.639 & 2.128 & 10.544 \\
\hline $\mathrm{Katoh}^{(32)}$ & 1996 & 60 & 43.2 & 79 & 56.8 & 71 & 56.3 & 55 & 43.7 & 0.591 & 0.364 & 0.959 & 16.364 \\
\hline Deakin $^{(14)}$ & 1996 & 64 & 47.1 & 72 & 52.9 & 261 & 45.2 & 316 & 54.8 & 1.077 & 0.741 & 1.564 & 27.563 \\
\hline Liakhovich $^{(42)}$ & 1997 & 28 & 57.1 & 21 & 42.9 & 32 & 60.4 & 21 & 39.6 & 0.877 & 0.401 & 1.915 & 6.294 \\
\hline $\mathrm{Ng}^{(54)}$ & 1998 & 23 & 45.1 & 28 & 54.9 & 22 & 62.9 & 13 & 37.1 & 0.495 & 0.208 & 1.179 & 5.098 \\
\hline Wang ${ }^{(81)}$ & 1998 & 34 & 41.0 & 49 & 59.0 & 43 & 51.8 & 40 & 48.2 & 0.649 & 0.353 & 1.194 & 10.323 \\
\hline Alves $^{(3)}$ & 1998 & 77 & 52.0 & 71 & 48.0 & 40 & 47.6 & 44 & 52.4 & 1.191 & 0.699 & 2.030 & 13.504 \\
\hline $\mathrm{Oda} a^{(56)}$ & 1999 & 56 & 38.1 & 91 & 61.9 & 57 & 50.9 & 55 & 49.1 & 0.596 & 0.363 & 0.979 & 15.616 \\
\hline Jiang $^{(29)}$ & 2000 & 17 & 41.5 & 24 & 58.5 & 27 & 65.9 & 14 & 34.1 & 0.377 & 0.156 & 0.911 & 4.919 \\
\hline $\operatorname{Liu}^{(4)}$ & 2000 & 36 & 36.4 & 63 & 63.6 & 178 & 48.9 & 186 & 51.1 & 0.601 & 0.381 & 0.941 & 18.481 \\
\hline $\mathrm{Cai}^{(8)}$ & 2001 & 35 & 36.8 & 60 & 63.2 & 51 & 54.3 & 43 & 45.7 & 0.496 & 0.278 & 0.884 & 11.481 \\
\hline Qian $^{(60)}$ & 2001 & 34 & 38.2 & 55 & 61.8 & 50 & 53.2 & 44 & 46.8 & 0.548 & 0.305 & 0.984 & 11.201 \\
\hline Shen ${ }^{(70)}$ & 2001 & 67 & 55.4 & 54 & 44.6 & 80 & 66.1 & 41 & 33.9 & 0.638 & 0.381 & 1.071 & 14.351 \\
\hline Saadat ${ }^{(66)}$ & 2001 & 16 & 38.1 & 26 & 61.9 & 78 & 59.5 & 53 & 40.5 & 0.424 & 0.209 & 0.860 & 7.706 \\
\hline Setiawan ${ }^{(68)}$ & 2001 & 45 & 51.7 & 42 & 48.3 & 207 & 49.4 & 212 & 50.6 & 1.096 & 0.692 & 1.736 & 18.171 \\
\hline $\operatorname{Lan}^{(38)}$ & 2001 & 180 & 51.9 & 167 & 48.1 & 204 & 47.9 & 222 & 52.1 & 1.172 & 0.883 & 1.556 & 47.859 \\
\hline $\mathrm{Wu}^{(84)}$ & 2002 & 183 & 51.4 & 173 & 48.6 & 142 & 51.1 & 136 & 48.9 & 1.013 & 0.741 & 1.386 & 39.128 \\
\hline $\mathrm{Gao}^{(18)}$ & 2002 & 63 & 41.2 & 90 & 58.8 & 90 & 40.4 & 133 & 59.6 & 1.035 & 0.682 & 1.571 & 22.056 \\
\hline Gong $^{(21)}$ & 2002 & 7 & 21.9 & 25 & 78.1 & 38 & 43.2 & 50 & 56.8 & 0.386 & 0.154 & 0.964 & 4.580 \\
\hline Zheng $^{(94)}$ & 2002 & 28 & 30.4 & 64 & 69.6 & 44 & 47.8 & 48 & 52.2 & 0.482 & 0.264 & 0.877 & 10.674 \\
\hline Sgambato ${ }^{(69)}$ & 2002 & 3 & 37.5 & 5 & 62.5 & 47 & 47.0 & 53 & 53.0 & 0.717 & 0.177 & 2.895 & 1.971 \\
\hline Choi ${ }^{(10)}$ & 2003 & 34 & 42.5 & 46 & 57.5 & 82 & 46.3 & 95 & 53.7 & 0.859 & 0.506 & 1.459 & 13.683 \\
\hline Zhang $^{(90)}$ & 2003 & 49 & 38.6 & 78 & 61.4 & 61 & 53.5 & 53 & 46.5 & 0.549 & 0.329 & 0.914 & 14.729 \\
\hline Zheng $^{(93)}$ & 2003 & 168 & 53.7 & 145 & 46.3 & 106 & 55.2 & 86 & 44.8 & 0.941 & 0.656 & 1.348 & 29.623 \\
\hline Zhou $^{(95)}$ & 2003 & 12 & 63.2 & 7 & 36.8 & 44 & 61.1 & 28 & 38.9 & 1.067 & 0.385 & 2.961 & 3.691 \\
\hline Colombo $^{(12)}$ & 2004 & 53 & 53.0 & 47 & 47.0 & 88 & 58.7 & 62 & 41.3 & 0.795 & 0.479 & 1.321 & 14.916 \\
\hline Gonzalez $^{(22)}$ & 2004 & 16 & 51.6 & 15 & 48.4 & 25 & 49.0 & 26 & 51.0 & 1.106 & 0.458 & 2.670 & 4.949 \\
\hline Torres $^{(78)}$ & 2004 & 16 & 34.8 & 30 & 65.2 & 60 & 62.5 & 36 & 37.5 & 0.326 & 0.158 & 0.675 & 7.282 \\
\hline Roth $^{(64)}$ & 2004 & 66 & 73.3 & 24 & 26.7 & 309 & 68.1 & 145 & 31.9 & 1.276 & 0.771 & 2.111 & 15.161 \\
\hline Suzuki ${ }^{(76)}$ & 2004 & 58 & 40.0 & 87 & 60.0 & 93 & 52.5 & 84 & 47.5 & 0.604 & 0.388 & 0.941 & 19.588 \\
\hline Shen $^{(72)}$ & 2004 & 29 & 48.3 & 31 & 51.7 & 36 & 60.0 & 24 & 40.0 & 0.629 & 0.307 & 1.288 & 7.471 \\
\hline Shen ${ }^{(71)}$ & 2005 & 71 & 50.0 & 71 & 50.0 & 314 & 46.5 & 361 & 53.5 & 1.149 & 0.801 & 1.649 & 29.483 \\
\hline $\mathrm{Lai}^{(37)}$ & 2005 & 50 & 40.7 & 73 & 59.3 & 66 & 54.5 & 55 & 45.5 & 0.573 & 0.346 & 0.950 & 15.046 \\
\hline $\mathrm{Li}^{(41)}$ & 2005 & 33 & 33.0 & 67 & 67.0 & 36 & 58.1 & 26 & 41.9 & 0.360 & 0.188 & 0.690 & 9.108 \\
\hline $\mathrm{Mu}^{(51)}$ & 2005 & 69 & 35.2 & 127 & 64.8 & 158 & 40.2 & 235 & 59.8 & 0.810 & 0.568 & 1.155 & 30.500 \\
\hline $\operatorname{Nan}^{(52)}$ & 2005 & 149 & 37.3 & 251 & 62.8 & 254 & 41.4 & 360 & 58.6 & 0.842 & 0.650 & 1.090 & 57.576 \\
\hline $\mathrm{Nan}^{(53)}$ & 2005 & 34 & 31.8 & 73 & 68.2 & 90 & 40.9 & 130 & 59.1 & 0.677 & 0.417 & 1.100 & 16.312 \\
\hline Tamer $^{(77)}$ & 2005 & 30 & 42.9 & 40 & 57.1 & 116 & 56.9 & 88 & 43.1 & 0.572 & 0.332 & 0.987 & 12.926 \\
\hline $\mathrm{Lee}^{(40)}$ & 2006 & 60 & 82.2 & 13 & 17.8 & 207 & 78.7 & 56 & 21.3 & 1.220 & 0.631 & 2.359 & 8.840 \\
\hline Hong ${ }^{(27)}$ & 2006 & 48 & 44.4 & 60 & 55.6 & 104 & 43.7 & 134 & 56.3 & 1.320 & 0.654 & 1.628 & 18.467 \\
\hline Zhou $^{(96)}$ & 2006 & 33 & 33.0 & 67 & 67.0 & 36 & 58.1 & 26 & 41.9 & 0.360 & 0.188 & 0.690 & 9.108 \\
\hline Agudo $^{(1)}$ & 2006 & 120 & 49.6 & 122 & 50.4 & 434 & 46.6 & 498 & 53.4 & 1.129 & 0.851 & 1.497 & 48.147 \\
\hline Martinez ${ }^{(47)}$ & 2006 & 65 & 66.3 & 33 & 33.7 & 180 & 54.7 & 149 & 45.3 & 1.619 & 1.013 & 2.589 & 17.438 \\
\hline Wideroff ${ }^{83)}$ & 2007 & 55 & 47.4 & 61 & 52.6 & 87 & 41.8 & 121 & 58.2 & 1.253 & 0.795 & 1.975 & 18.540 \\
\hline Tripathi $^{(79)}$ & 2007 & 45 & 59.2 & 31 & 40.8 & 61 & 61.0 & 39 & 39.0 & 0.928 & 0.507 & 1.699 & 10.493 \\
\hline Boccia $^{(5)}$ & 2007 & 48 & 44.9 & 59 & 55.1 & 119 & 46.9 & 135 & 53.1 & 0.924 & 0.588 & 1.452 & 18.806 \\
\hline Ruzzo $^{(65)}$ & 2007 & 91 & 72.2 & 35 & 27.8 & 83 & 57.6 & 61 & 42.4 & 1.898 & 1.142 & 3.157 & 14.851 \\
\hline Al-Moundhri ${ }^{(2)}$ & 2009 & 65 & 60.7 & 42 & 39.3 & 75 & 70.1 & 32 & 29.9 & 0.663 & 0.377 & 1.166 & 12.076 \\
\hline Masoudi $^{(48)}$ & 2009 & 30 & 44.8 & 37 & 55.2 & 74 & 55.2 & 60 & 44.8 & 0.660 & 0.368 & 1.187 & 11.185 \\
\hline Malik ${ }^{(46)}$ & 2009 & 44 & 40.7 & 64 & 59.3 & 116 & 59.5 & 79 & 40.5 & 0.471 & 0.292 & 0.758 & 16.910 \\
\hline $\operatorname{Moy}^{(50)}$ & 2009 & 72 & 42.4 & 98 & 57.6 & 320 & 43.5 & 415 & 56.5 & 0.954 & 0.682 & 1.336 & 33.930 \\
\hline $\mathrm{PiaO}^{(59)}$ & 2009 & 988 & 44.6 & 1225 & 55.4 & 776 & 45.7 & 923 & 54.3 & 0.959 & 0.845 & 1.089 & 238.192 \\
\hline Huang ${ }^{(28)}$ & 2009 & 55 & 45.5 & 66 & 54.5 & 84 & 60.9 & 54 & 39.1 & 0.538 & 0.329 & 0.881 & 15.813 \\
\hline Zendehdel $^{(87)}$ & 2009 & 54 & 43.5 & 70 & 56.5 & 230 & 49.0 & 239 & 51.0 & 0.803 & 0.540 & 1.195 & 24.362 \\
\hline Nguyen ${ }^{(55)}$ & 2010 & 16 & 27.1 & 43 & 72.9 & 34 & 31.2 & 75 & 68.8 & 0.830 & 0.414 & 1.664 & 7.948 \\
\hline Yadav ${ }^{(85)}$ & 2010 & 84 & 63.2 & 49 & 36.8 & 150 & 55.6 & 120 & 44.4 & 1.367 & 0.894 & 2.090 & 21.286 \\
\hline Palli $^{(57)}$ & 2010 & 130 & 43.9 & 166 & 56.1 & 271 & 49.6 & 275 & 50.4 & 0.795 & 0.599 & 1.056 & 47.660 \\
\hline $\operatorname{Darazy}^{(13)}$ & 2011 & 7 & 53.8 & 6 & 46.2 & 58 & 82.9 & 12 & 17.1 & 0.247 & 0.073 & 0.831 & 2.602 \\
\hline $\operatorname{Luo}^{(44)}$ & 2011 & 30 & 24.4 & 93 & 75.6 & 58 & 45.0 & 71 & 55.0 & 0.399 & 0.233 & 0.610 & 13.412 \\
\hline Zhang $^{(88)}$ & 2011 & 89 & 45.9 & 105 & 54.1 & 218 & 52.9 & 194 & 47.1 & 0.755 & 0.534 & 1.063 & 32.927 \\
\hline Yadav $^{(86)}$ & 2011 & 30 & 73.2 & 11 & 26.8 & 92 & 70.8 & 38 & 29.2 & 1.104 & 0.508 & 2.397 & 6.389 \\
\hline Jing $^{(30)}$ & 2012 & 170 & 41.5 & 240 & 58.5 & 203 & 49.5 & 207 & 50.5 & 0.723 & 0.549 & 0.952 & 50.617 \\
\hline Malakar ${ }^{(45)}$ & 2012 & 45 & 44.1 & 57 & 55.9 & 107 & 52.5 & 97 & 47.5 & 0.718 & 0.446 & 1.155 & 16.970 \\
\hline Wang $^{(82)}$ & 2012 & 90 & 69.8 & 39 & 30.2 & 112 & 81.2 & 26 & 18.8 & 0.540 & 0.307 & 0.949 & 12.050 \\
\hline $\operatorname{Kim}^{(33)}$ & 2012 & 41 & 40.2 & 61 & 59.8 & 76 & 38.0 & 124 & 62.0 & 1.098 & 0.676 & 1.785 & 16.271 \\
\hline Garcia-Gonzalez $^{(19)}$ & 2012 & 274 & 49.2 & 283 & 50.8 & 290 & 52.1 & 267 & 47.9 & 0.892 & 0.705 & 1.128 & 69.682 \\
\hline Eom $^{(16)}$ & 2013 & 214 & 44.9 & 263 & 55.1 & 217 & 45.6 & 259 & 54.4 & 0.971 & 0.753 & 1.253 & 59.142 \\
\hline Haholu ${ }^{(24)}$ & 2013 & 24 & 48.0 & 26 & 52.0 & 32 & 56.1 & 25 & 43.9 & 0.725 & 0.341 & 1.554 & 6.732 \\
\hline Total & & 5154 & 46.0 & 6054 & 54.0 & 8736 & 50.4 & 8605 & 49.6 & 0.788 & 0.725 & 0.857 & $P<0.0001$ \\
\hline
\end{tabular}


The heterogeneity chi-square test was used in $2 \times 2$ tables of all the possibilities: Asia $\left(\chi^{2}=99,489 ; \mathrm{DF}=49 ; P<0.0001\right)$; Europe $\left(\chi^{2}=22.800 ; \mathrm{DF}=11, P=0.019\right) ;$ America $\left(\chi^{2}=10.774 ; \mathrm{DF}=4\right.$; $P=0.029)$; Eurasia $\left(\chi^{2}=0.820 ; \mathrm{DF}=2, P=0.664\right)$; and finally, gathering all studies $\left(\chi^{2}=154,651 ; \mathrm{DF}=69 ; P<0.0001\right)$. Thus, tests have revealed significant $(P<0.05)$ with the American, Asian and European groupings, indicating that there is a difference between them only as a result of sampling error, i.e., the real effect is the same in each of the studies. However, in the Eurasia group, the test is found to be significant $(P>0.05)$. However, data from all articles analyzed points to the same statistical direction $(P<0.0001)$, then it is concluded that when all the samples are grouped, the articles are homogeneous and differences can be seen as resulting from random or common effects.

Table 2 shows an overview of all groups, with their heterogeneity $\chi^{2}$ tests, indicating the $P$-value, which determines the type of test used in the meta-analysis. Verification tests of the correlation of the GSTM1 gene polymorphism with gastric cancer, in various grouping situations, were sometimes random effects of DerSimonian-Laird, and at other times of fixed effect Mantel-Haenszel. It can be observed in Table 2 that the $p$ values, in the meta-analysis, revealed no association between the variables studied $(P>0.05)$ in Europe and America, and for the grouping of studies in Asia and Eurasia could be inferred that there is a positive association (Asia, $P<0.0001$ and Eurasia, $P=0.05$ ).

The data in Table 2 indicates that the meta-analysis of 70 casecontrol studies investigating the association between polymorphisms of GSTM1 and the risk of developing gastric cancer was positively correlated, and therefore the presence of the gene a protective factor. Regarding the groupings performed, there is a positive correlation in the group of Asian and Eurasian studies, but no correlation was observed in studies conducted in Europe and America.

\section{DISCUSSION}

The pathogenesis of gastric cancer is not yet fully known. In recent years, it was understood that the knowledge that the process of developing this cancer is multifactorial, in which the environment and genetic susceptibility factors are decisive ${ }^{(35)}$.

Among the biological factors, infection by the bacterium Helicobacter pylori plays an important correlation with gastric cancer due to their role in chronic atrophic gastritis, since gastric carcinoma is accompanied by hypochlorhydria in $85 \%$ to $90 \%$ of cases ${ }^{(39)}$.

The $H$. pylori infection still remains the greatest risk factor for the development of gastric cancer, increasing the incidence of this cancer about six times. It is one of the most common infec- tions of the population, with a worldwide prevalence estimated at between $50 \%$ and $90 \%$ in developing countries. However, it is important to mention that, in populations with a high prevalence of infection by $H$. pylori, a small fraction of infected develop gastric cancer ${ }^{(74)}$.

The risk of intestinal metaplasia in the gastric antrum depends largely on the presence of a peptic ulcer and other factors, such as individual variability of the immune response, advanced age, smoking, chronic alcohol abuse, and eating habits. Therefore, additional factors alter the relationship of $H$. pylori to gastric carcinogenesis ${ }^{(61)}$. Chen and colleagues showed that risk factors such as smoking and Helicobacter pylori infection did not modify the association between GSTMI null and risk for gastric cancer, suggesting greater genetic influence in the etiology of this cancer ${ }^{(9)}$.

Significant associations of the absence of the GSTM1 gene and the incidence of gastric cancer were found in Asians, but it was not possible to demonstrate such an outcome in Caucasian and African populations, suggesting a possible influence of ethnic differences, genetic origins and the environment. The influence of GSTM1 null allele can be masked by the presence of other causative genes, not yet identified, involved in the development of gastric cancer in Caucasians and Africans ${ }^{(34,61,97)}$.

According to Rebbeck and colleagues, ethnic differences were found related to the prevalence of GSTMI deletion gene in different populations. In Japanese, this frequency varies between $48 \%$ to $51 \%$ of the population, in Chinese between $35 \%$ to $65 \%$, in Indians $33 \%$ to $36 \%, 50 \%$ in Caucasians and Africans $22 \%$ to $35 \%{ }^{(62)}$.

Another risk factor that already has well-established relationship in the genesis of gastric cancer is smoking. It is estimated that smoking increases the risk of this cancer by $50 \%$. A meta-analysis conducted in 2008 by Ladeiras-Lopes and colleagues estimated that smoking is the main modifiable risk factor related to gastric cancer, especially in men ${ }^{(36)}$.

Tobacco is composed of more than 4,000 different compounds, 50 proven carcinogens. Pollutants such as benzopyrene and other polycyclic aromatic hydrocarbons are substrates of enzymes of the GST family and have serious carcinogenic activity. These compounds are primarily metabolized by Phase I enzymes, detoxified and converted into inactive metabolites by enzymes of Phase II, enzymes expressed by the gene GSTM1 ${ }^{(39)}$.

The null genotype refers to the complete absence of enzyme activity $G S T M 1$, and can thus increase the risk of gastric cancer. The lack of function of this gene leads to the accumulation of toxic intermediate, resulting in greater damage to DNA, which facilitates carcinogenesis $^{(25,36,61)}$.

TABLE 2. Summary of the groupings, showing the chi-square test of heterogeneity and the type of the test realized in the meta-analysis.

\begin{tabular}{|c|c|c|c|c|c|c|c|c|c|}
\hline \multirow{2}{*}{ Parameters } & \multirow{2}{*}{$\begin{array}{l}\text { Number } \\
\text { of studies }\end{array}$} & \multicolumn{3}{|c|}{ Heterogeneity } & \multicolumn{5}{|c|}{ Meta-analysis } \\
\hline & & $\chi^{2}$ & $\mathrm{gl}$ & $P$-value & Test & OR & CI $(95 \%)$ & CI $(95 \%)$ & $P$-value \\
\hline \multicolumn{10}{|l|}{ Geral } \\
\hline \multicolumn{10}{|l|}{ Region } \\
\hline America & 5 & 10.774 & 4 & 0.0292 & DSL & 0.866 & 0.549 & 1.364 & 0.534 \\
\hline Europe & 12 & 22.800 & 11 & 0.0189 & DSL & 1.033 & 0.873 & 1.222 & 0.705 \\
\hline
\end{tabular}

DSL: DerSimonian-Laird; MH: Mantel-Haenszel. 


\section{CONCLUSION}

The meta-analysis included 70 articles published between 1991 and 2015. The group generated a simultaneous universal evaluation of the GSTM1 null polymorphism in 28,549 individuals, 11,208 patients with gastric cancer and 17,341 controls.

The current study showed that there is a significant positive association between GSTM1 null genotype and gastric cancer, with $P<0.0001$. The presence of GSTM1 gene is protective in cases of gastric cancer $(\mathrm{OR}=0.788)$.

Prior studies of this association are quite controversial. The work carried out in Asia are those that showed strong correlation between variables $(P<0.001)$; on the other hand, as reported in previous references, the data collected in Europe $(P=0.705)$ and the Americas $(P=0.534)$ did not find such an association. It is important to note the composition of this meta-analysis, the Asian articles contributed 20,257 individuals, 8,465 cases and 11,792 controls. The Americas articles contributed 1,134 individuals ( 366 cases and 768 controls) and European data with 6,675 individuals (2,208 cases and 4,467 controls).
The process of carcinogenesis is multifactorial and not fully understood. Genetic susceptibility may modify the effect of environmental exposure, thus explaining the variations in the incidence of gastric cancer around the world and the results found in this meta-analysis: positive relationship between GSTM1 null and gastric cancer, especially when considering Asian countries.

Future studies with larger range of individuals are needed to better understand the association between GSTMI null and gastric cancer, especially in the continents in which such an association were not found, such as Europe and the Americas.

\section{Authors' contributions}

Ribeiro RX: performed research, drafted the research project, took data collection, wrote the preliminary versions of the article. Nascimento CILL: performed research, drafted the research project, took data collection, wrote the preliminary versions of the article. Silva AMTC: oriented study at all stages of execution, did the study statistics and edited the preliminary versions of the article, generating the final version.

Ribeiro RX, Nascimento CILL, Silva AMTC. Associação do genótipo nulo GSTM1 e o câncer gástrico: evidências baseadas em meta-análise. Arq Gastroenterol. 2017;54(2):101-8.

RESUMO - Contexto - No Brasil, o câncer gástrico é o quarto mais comum em homens e o sexto entre as mulheres, excetuando-se os tumores de pele não melanoma. Aspectos epidemiológicos evidenciam a etiologia multifatorial desta neoplasia, destacando como fatores de risco: a infecção pela bactéria Helicobacter pylori, idade avançada, tabagismo, etilismo crônico, hábitos alimentares e polimorfismos genéticos. No contexto dos polimorfismos genéticos, tem-se a ausência do gene GSTM1. A falta da função de GSTM1 em detoxificar xenobióticos e promover defesa contra o estresse oxidativo, leva ao maior dano do DNA, favorecendo a carcinogênese gástrica. Este processo é multifatorial e o desenvolvimento do câncer gástrico resulta de uma interação complexa dessas variáveis. Objetivo - O objetivo do presente estudo foi investigar a associação do polimorfismo nulo de GSTM1 na gênese do câncer gástrico. Métodos - Foi conduzida uma meta-análise a partir de 70 artigos colhidos dos bancos de dados: SciELO e PubMed, entre setembro de 2015 e julho de 2016. Para avaliar uma possível associação, utilizou-se o odds ratio (OR) e intervalo de confiança de $95 \%$ (IC 95\%). Para avaliar a heterogeneidade dos estudos, utilizou-se o teste do qui-quadrado. A análise estatística foi realizada utilizando-se o BioEstat ${ }^{\mathbb{R}}$ 5.3. Resultados - A presente pesquisa contou com 70 estudos do tipo caso-controle que incluíram 28.549 indivíduos avaliados para o polimorfismo nulo do gene GSTM1, dos quais 11.208 (39,26\%) eram casos e $17.341(60,74 \%)$ eram controles. A análise final mostra que a presença do gene GSTMI funciona como um fator de proteção contra o desenvolvimento de câncer gástrico (OR=0,788; IC95\% 0,725-0,857; $P<0,0001)$. Associação estatística positiva foi encontrada na Ásia (OR=0,736; IC95\% 0,670-0,809; $P<0,0001)$ e Eurásia (OR=0,671; IC95\% 0,456-0,988; $P=0,05)$. No entanto, não temos dados com significância estatística da Europa $(\mathrm{OR}=1,033 ; \mathrm{IC} 95 \% 0,873-1,222 ; P=0,705)$ e América $(\mathrm{OR}=0,866 ; \mathrm{IC} 95 \% 0,549-1,364 ; P=0,534)$ para inferir proteção ao câncer gástrico no mundo. Conclusão - Esta meta-análise, conclui que a presença do gene GSTM1 é protetora para o surgimento do câncer gástrico, principalmente nos países asiáticos, porém tal resultado não foi encontrado se comparado isoladamente os estudos realizados na Europa e na América.

DESCRITORES - Neoplasias gástricas. Polimorfismo genético. Meta-análise.

\section{REFERENCES}

1. Agudo A, Sala N, Pera G, Capellá G, Berenguer A, García N, et al. No association between polymorphisms in CYP2E1, GSTM1, NAT1, NAT2 and the risk of gastric adenocarcinoma in the European prospective investigation into cancer and nutrition. Cancer Epidemiol Biomarkers Prev. 2006;15:1043-5.

2. Al-Moundhri MS, Alkindy M, Al-Nabhani M, Al-Bahrani B, Burney IA, Al-Habsi $\mathrm{H}$, et al. Combined polymorphism analysis of glutathione S-transferase M1/G1 and interleukin-1B (IL-1B)/interleukin 1-receptor antagonist (IL-1RN) and gastric cancer risk in an Omani Arab Population. J Clin Gastroenterol. 2009;43:152-6.

3. Alves GM. Glutathione $\mathrm{S}$ transferase mu polymorphism and gastric cancer in the Portuguese population. Biomarkers. 1998;3:441-7.

4. Ayres M, Ayres Jr. M, Ayres DL, Santos AS. BioEstat: aplicações estatísticas nas áreas das ciências bio-médicas. Belém: Sociedade Civil Mamirauá; 2007. p. 132-214.

5. Boccia S, Sayed-Tabatabaei FA, Persiani R, Gianfagna F, Rausei S, Arzani, D, et al. Polymorphisms in metabolic genes, their combination and interaction with tobacco and alcohol consumption and risk of gastric cancer: a case-control study in an Italian population. BMC Cancer. 2007;7:206.
6. Böhning D, Malzahn U, Dietz E, Schlattmann P. Some general points in estimating heterogeneity variance with the DerSimonian-Laird estimator. Biostatistics. 2002;3:445-57.

7. Bustamante-Teixeira MT, et al. Sobrevida em pacientes com câncer gástrico em Campinas, São Paulo, Brasil. Cad. Saúde Pública. 2006;22:1611-8.

8. Cai L, Yu SZ, Zhang ZF. Glutathione S-transferases M1, T1 genotypes and the risk of gastric cancer: a case-control study. World J Gastroenterol. 2001;7:506-9.

9. Chen B, Zhou Y, Yang P, Wu X. Glutathione S-transferase M1 gene polymorphism and gastric cancer risk: an updated analysis. Arch Med Res. 2010;41:558-66.

10. Choi SC, Yun KJ, Kim TH, Kim HJ, Park SG, Oh GJ, et al. Prognostic potential of glutathione S-transferase M1 and T1 null genotypes for gastric cancer progression. Cancer Lett. 2003;195:169-75.

11. Cola $\mathrm{CB}$, et al. Tratamento cirúrgico do câncer gástrico em pacientes jovens: experiência de 05 anos no INCA. Revista Brasileira de Cancerologia. 2005;51:135-41.

12. Colombo J, Rossit AR, Caetano A, Borim AA, Wornrath D, Silva AE. GSTT1, GSTM1 and CYP2E1 genetic polymorphisms in gastric cancer and chronic gastritis in a Brazilian population. World J Gastroenterol. 2004;10:1240-5. 
13. Darazy M, Balbaa M, Mugharbil A, Saeed H, Sidani H, Abdel-Razzak Z. CYP1A1, CYP2E1, and GSTM1 gene polymorphisms and susceptibility to colorectal and gastric cancer among Lebanese. Genet Test Mol Biomarkers. 2011;15:423-9.

14. Deakin M, Elder J, Hendrickse C, Peckham D, Baldwin D, Pantin C, et al. Glutathione S-transferase GSTT1 genotypes and susceptibility to cancer: studies of interactions with GSTM1 in lung, oral, gastric and colorectal cancers. Carcinogenesis. 1996;17:881-4.

15. Domenico P, Saieva C, Gemma S, Masala G, Gomez-Miguel MJ, Luzzi I, et al GSTT1 and GSTM1 gene polymorphisms and gastric cancer in a high-risk Italian population. Int. J. Cancer. 2005;115:284-9.

16. Eom SY, Yim DH, Zhang Y, Yun JK, Moon SI, Yun HY, et al. Dietary aflatoxin Blintake, genetic polymorphisms of CYP1A2, CYP2E1, EPHX1, GSTM1, and GSTT1, and gastric cancerrisk in Korean. Cancer Causes Control. 2013;24: 1963-72.

17. Ferlay J, Soerjomataram I, Ervik M, Dikshit R, Eser S, Mathers C, et al.Cancer Incidence and Mortality Worldwide: IARC Cancer Base No. 11. [Internet]. [Accessed 2015 november 6]. Available from: http://globocan.iarc.fr.

18. Gao CM, Takezaki T, Wu JZ, Li ZY, Liu YT, Li SP, et al. Glutathione-S-transferases M1 (GSTM1) and GSTT1 genotype, smoking, consumption of alcohol and tea and riskof esophageal andstomach cancers:a case-control study of a high-incidence area in Jiang su Province. China Cancer Lett. 2002;188:95-102.

19. Garcia-Gonzalez MA, Quintero E, Bujanda L, Nicolas D, Benito R, Strunk M, et al. Relevance of GSTM1, GSTT1, and GSTP1 gene polymorphisms to gastric cancer susceptibility and phenotype. Mutagenesis. 2012;27:771-7.

20. Giannotti JG, Packer IU, Mercadante MEZ. Meta-análise para estimativas de correlação genética entre pesos ao nascer e desmama de bovinos. Scientia Agricola. 2002:59:435-40.

21. Gong L, Sun HL, Xu YQ. The study of correlations between the deletion of GSTM1 gene and gastric cancer. Wan Nan Yi Xue Yuan Xue Bao. 2002;21:181-3.

22. Gonzalez A, Ramirez V, Cuenca P, Sierra R. Polymorphisms in detoxification genes CYP1A1, CYP2E1, GSTT1 and GSTM1 in gastric cancer susceptibility. Rev Biol Trop. 2004;52:591-600.

23. $\mathrm{Gu}$ J, et al. GSTM1 null genotype is associated with increased risk of gastric ycancer in both ever-smokers and non-smokers: a meta-analysis of casa-control studies. Tumour Biol. 2014;35:3439-45.

24. Haholu A, Berber U, Karagoz B, Tuncel T, Bilgi O, Demirel D. Is there any association of glutathione S-transferase T1 (GSTT1) and glutathione S-transferase M1 (GSTM1) gene polymorphism with gastric cancers? Pol J Pathol. 2013;64:247-52.

25. Harada S, Misawa S, Nakamura T, Tanaka N, Ueno E, Nozoe M. Detection of GST1 gene deletion by the polymerase chain reaction and its possible correlation with stomach cancer in Japanese. Hum Genet. 1992;90:62-4.

26. Higgins JPT, White IR, Wood AM. Imputation methods for missing outcome data in metaanalysis of clinical trials. Clinical Trials. 2008;5:225-39.

27. Hong SH, Kim JW, Kim HG, Park IK, Ryoo JW, Lee CH, et al. Glutathione S-transferases (GSTM1, GSTT1 and GSTP1) and N-acetyltransferase 2 polymorphisms and the riskof gastriccancer. J Prev Med Public Health. 2006;39:135-140.

28. Huang X, Lu YF, Xie NC, Zhang HT, Ning Z, Tan ZR. A case-control study on the association between genetic polymorphism of GSTM1 and gastric cancer susceptibility in population from Guangxi province of China. Wei Chang Bing Xue He Gan Bing Xue Za Zhi. 2009;18:97-9.

29. Jiang YH, Ju ZY, Ren CS. Study on the relationship between the glutathiones-transferase gene deletion environmental factors and susceptibility to gastric carcinoma. Zhong Guo Gong Gong Wei Sheng. 2000;16:877-9.

30. Jing C, Huang ZJ, Duan YQ, Wang PH, Zhang R, Luo KS, Xiao XR. Glulathione-S-transferases gene polymorphism in prediction of gastric cancer risk by smoking and Helicobacter pylori infection status. Asian Pac J Cancer Prev. 2012;13:3325-8.

31. Kato S, Onda M, Matsukura N, Tokunaga A, Matsuda N, Yamashita K, Shields PG. Genetic polymorphisms of the cancer related gene and Helicobacter pylori infection in Japanese gastric cancer patients. An age and gender matched casecontrol study. Cancer. 1996;77(8 Suppl):1654-61.

32. Katoh T, Nagata N, Kuroda Y, Itoh H, Kawahara A, Kuroki N, et al. GlutathioneS-transferase M1 (GSTM1) and T1 (GSTT1) genetic polymorphism and susceptibilityto gastric and colorectal adenocarcinoma. Carcinogenesis. 1996;17:1855-9.

33. Kim H, Um J, Kim Y. Glutathione S-transferase gene polymorphism in Korean subjects with gastric and colorectal cancer. Oriental Pharmacy and Experimental Medicine. 2012;12:307-12.

34. La Torre G, Boccia S, Ricciardi G. Glutathione S-transferase M1 status and gastric cancer risk: a meta-analysis. Cancer Letters. 2005;217:53-60.

35. La Torre G, Chiaradia G, Gianfagna F, De Lauretis A, Boccia S, Mannocci A, Ricciardi W. Smoking status and gastric cancer risk: an updated meta-analysis of case-control studies published in the past ten years. Tumori. 2009;95:13-22.
36. Ladeiras-Lopes R, Pereira AK, Nogueira A, Pinheiro-Torres T, Pinto I, Santos-Pereira R, Lunet N. Smoking and gastric cancer: systematic review and metaanalysis of cohort studies. Cancer Causes Control. 2008;19:689-701.

37. Lai KC, Chen WC, Tsai FJ, Li SY, Chou MC, Jeng LB. GlutathioneS-transferase M1 gene null genotype and gastric cancer risk in Taiwan. Hepatogastroenterology. 2005;52:1916-9.

38. Lan Q, Chow WH, Lissowska J, Hein DW, Buetow K, Engel LS, Ji B, Zatonski W, Rothman N. Glutathione S-transferase genotypes and stomach cancer in a population-based case-control study in Warsaw. Poland Pharmacogenetics. 2001;11:655-61.

39. Lao X, Peng Q, Lu Y, Li S, Qin X, Chen Z, Chen J. Glutathione S-transferase gene GSTM1, gene-gene interaction, and gastric cancer susceptibility: evidence from an uptodate meta-analysis. Cancer Cell Int. 2014;14:127.

40. Lee K, Caceres D, Varela N, Csendes DA, Rios RH, Quinones SL. Allelic variants of cytochrome P4501A1 (CYP1A1), glutathione S transferase M1 (GSTM1) polymorphisms and their association with smoking and alcohol consumption as gastric cancer susceptibility biomarkers. Rev Med Chil. 2006;134:1107-15.

41. Li H, Chen XL, Li HQ. Polymorphism of CYPIA1 and GSTM1 genes associated with susceptibility of gastric cancer in Shandong Province of China. World J Gastroenterol. 2005; 11:5757-62.

42. Liakhovich VV, Vavilin VA, Gutkina NI, Laktionova IP, Makarova SI, Mitrofanov DV, et al. Genes and enzymes of the xenobiotic-metabolizing system in cancer pathology. Vopr Med Khim. 1997;43:330-38.

43. Liu Y, Xu RT, Sun GF, Shang XL, Wang Q. The relationship of GSTM1 gene homozygous deletion polymorphism of gastric cancer. Zhong Guo Yi Ke Da Xue Xue Bao. 2000;29:287-9.

44. Luo YP, Chen HC, Khan MA, Chen FZ, Wan XX, Tan B, Ou-Yang FD, Zhang DZ. Genetic polymorphisms of metabolic enzymes-CYP1A1, CYP2D6, GSTM1, and GSTT1, and gastric carcinoma susceptibility. Tumour Biol. 2011;32:215-22.

45. Malakar M, Devi KR, Phukan RK, Kaur T, Deka M, Puia L, et al. Genetic polymorphism of glutathione S-transferases M1 and T1, tobacco habits and risk of stomach cancer in Mizoram. India Asian Pac J Cancer Prev. 2012;13:4725-32.

46. Malik MA, Upadhyay R, Mittal RD, Zargar SA, Modi DR, Mittal B. Role of xenobiotic-metabolizing enzyme gene polymorphisms and interactions with environmental factors in susceptibility to gastric cancer in Kashmir Valley. J Gastrointest Cancer. 2009;40:26-32

47. Martinez C, et al. Glutathione S-transferases mu 1, theta 1, pi 1, alpha 1 and mu 3 genetic polymorphisms and the risk of colorectal and gastric cancers in humans. Pharmacogenomics. 2006;7:711-8

48. Masoudi M, Saadat I, Omidvari S, Saadat M. Genetic polymorphisms of GSTO2, GSTM1, and GSTT1 and risk of gastric cancer. Mol Biol Rep. 2009;36:781-4.

49. Meng X, et al. Glutathione S-transferase M1 null genotype meta-analysis on gastric câncer risk. Diagnostic Patology. 2014;9:122.

50. Moy KA, Yuan JM, Chung FL, Wang XL, Van Den Berg D, Wang R, Gao YT, Yu MC. Isothiocyanates, glutathioneS-transferase M1 and T1 polymorphisms and gastric cancer risk: a prospective study of men in Shanghai. China Int J Cancer. 2009;125:2652-9.

51. Mu LN, Lu QY, Yu SZ, Jiang QW, Cao W, You NC, et al. Green tea drinking and multigenetic index on the risk of stomach cancer in a Chinese population. Int J Cancer. 2005;116:972-83

52. Nan HM, Park JW, Song YJ, Yun HY, Park JS, Hyun T, et al. Kimchi and soybean pastes are risk factors of gastric cancer. World J Gastroenterol. 2005;11:3175-81.

53. Nan HM, Song YJ, Yun HY, Park JS, Kim H. Effects of dietary intake and genetic factors on hyper methylation of the hMLH1 gene promoter in gastric cancer. World J Gastroenterol. 2005;11:3834-41.

54. Ng EK, Sung JJ, Ling TK, Ip SM, Lau JY, Chan AC, et al. Helicobacter pylori and the null genotype of glutathione-S-transferasemu in patients with gastric adenocarcinoma. Cancer. 1998;82:268-73.

55. Nguyen TV, Janssen MJ, van Oijen MG, Bergevoet SM, te Morsche RH, van Asten H, Laheij RJ, et al. Genetic polymorphisms in GSTA1, GSTP1, GSTT1, and GSTM1 and gastric cancer risk in a Vietnamese population. Oncol Res. 2010;18:349-55.

56. Oda Y, Kobayashi M, Ooi A, et al. Genotypes of glutathione S-transferase $\mathrm{M} 1$ and $\mathrm{N}$-acetyltransferase 2 in Japanese patients with gastric cancer. Gastric Cancer. 1999;2:158-64.

57. Palli D, Polidoro S, D'Errico M, Saieva C, Guarrera S, Calcagnile AS, et al. Polymorphic DNA repair and metabolic genes: a multigenic study on gastric cancer. Mutagenesis. 2010;25:569-75.

58. Pereira MG, Galvão TF. Heterogeneidade e viés de publicação em revisões sistemáticas. Epidemiol. Serv. Saúde. 2014;23:775-8.

59. Piao JM, Shin MH, Kweon SS, Kim HN, Choi JS, Bae WK, et al. Glutathione-S-transferase (GSTM1, GSTT1) and the risk of gastrointestinal cancer in a Korean population. World J Gastroenterol. 2009;15:5716-21. 
60. Qian Y, Xu YC, Shen HB, et al. A molecular epidemiological study on the rela tionship between glutathione S-transferase M1, T1 genetic polymorphism and susceptibility to gastric cancer. Zhong Guo Gong Gong Wei Sheng. 2001;17:101-3.

61. Qiu LX, Wang K, Lv FF, et al. GSTM1 null allele is a risk factor for gastric cancer development in Asians. Cytokine. 2011;55:122-5.

62. Rebbeck TR. Molecular epidemiology of the human glutathione S-transferase genotypes GSTM1 and GSTT1 in cancer susceptibility. Cancer Epidemiol Biomarkers Prev. 1997;6:733-43.

63. Rodrigues CL, Ziegelmann PK. Metanálise: um guia prático. Rev HCPA 2010;30:436-47.

64. Roth MJ, Abnet CC, Johnson LL, Mark SD, Dong ZW, Taylor PR, Dawsey SM, Qiao YL. Polymorphic variation of Cyp1A1 is associated with the risk of gastric cardia cancer: a prospective case-cohort study of cytochrome P-4501A1 and GST enzymes. Cancer Causes Control. 2004;15:1077-83.

65. Ruzzo A, Canestrari E, Maltese P, Pizzagalli F, Graziano F, Santini D, et al. Polymorphisms in genes involved in DNA repair and metabolism of xenobiotics in individual susceptibility to sporadic diffuse gastric cancer. Clin. Clin Chem Lab Med. 2007;45:822-8.

66. Saadat I, Saadat M. Glutathione S-transferase M1 and T1 null genotypes and the risk of gastric and colorectal cancers. Cancer Lett. 2001;169:21-6.

67. Santos EJF, Cunha M. Interpretação crítica dos resultados estatísticos de uma meta-análise: Estratégias metodológicas. Millenium. 2013;85-8.

68. Setiawan VW, Zhang ZF, Yu GP, Li YL, Lu ML, Tsai CJ, et al. GSTT1 and GSTM1 null genotypes and the risk of gastric cancer: a case-control study in a Chinese population. Cancer Epidemiol Biomarkers Prev. 2000;9:73-80.

69. Sgambato A, Campisi B, Zupa A, Bochicchio A, Romano G, Tartarone A, et al. Glutathione S-transferase (GST) polymorphisms as risk factors for cancer in a highly homogeneous population from southern Italy. Anticancer Res. 2002;22(6B):3647-52.

70. Shen J, Wang R, Xu X. Application of the interaction models between the polymorphism(s) of metabolic gene(s) and environmental exposure. Zhonghua Liu Xing Bing Xue Za Zhi. 2001;22:61-4.

71. Shen XB, Pu XP, Zhang J, Zhu LJ. Influence of GSTM1 and GSTT1 genotypes and smoking, alcohol exposure on the occurrence of gastric cancer: case-contro study from Nanjing, China. Huan Jing Yu Zhi Ye Yi Xue. 2005;22:325-9,382.

72. Shen XB, Zhang J, Zhu LJ et al. Relationship between glutathione S-transferase M1, T1 genetic polymorphisms, smoking and alcohol consumption and susceptibility to stomach cancer. Huan Jing Yu Jian Kang Za Zhi. 2004;21:210-4.

73. Silva AMTC. O polimorfismo do gene p5372 (RP) no câncer de cabeça e pescoço: estudo de associação e meta-análise. Tese de doutorado em Biologia Molecular Universidade Federal de Goiás. 2009.

74. Silva JAG. Coordenação de Prevenção e Vigilância. Estimativa 2014: Incidência de Câncer no Brasil. Rio de Janeiro: INCA, 2014. [Internet]. [Accessed 2015 november 6]. Available from: http://www.inca.gov.br/estimativa/2014/estimativa-24042014.pdf

75. Strange RC, Matharoo B, Faulder GC, Jones P, Cotton W, Elder JB, Deakin $M$. The human glutathione S-transferases: a case-control study of the incidence of the GST1 0 phenotype in patients with adenocarcinoma. Carcinogenesis. 1991;12:25-8.

76. Suzuki S, Muroishi Y, Nakanishi I, Oda Y. Relationship between genetic polymorphisms of drug-metabolizing enzymes (CYP1A1, CYP2E1, GSTM1, and NAT2), drinking habits, histological subtypes, and p53 gene point mutations in Japanese patients with gastric cancer. J Gastroenterol. 2004;39:220-230

77. Tamer L, Ates NA, Ates C, Ercan B, Elipek T, Yildirim H, et al. Glutathione S-transferase M1, T1 and P1 genetic polymorphisms, cigarette smoking and gastric cancer risk. Cell Biochem Funct. 2005;23:267-72.
78. Torres MM, Acosta CP, Sicard DM. Groot de Restrepo H: Genetic susceptibility and risk of gastric cancer in a human population of Cauca. Colombia Biomedica. 2004;24:153-62.

79. Tripathi S, Ghoshal U, Ghoshal UC, Mittal B, Krishnani N, Chourasia D, et al Gastric carcinogenesis: possible role of polymorphisms of GSTM1, GSTT1, and GSTP1 genes. Scand J Gastroenterol. 2008;43:431-9.

80. WANG H, et al. Glutathione S-transferase M1 null genotype associated with gastric cancer among Asians. Dig Dis Sci. 2010;55:1824-30.

81. Wang KY, Lin JT, Chen CJ, et al. The relationship between the genotypesm of cancer susceptibility genes and the development of gastric cancer. Zhong Hua Gong Gong Wei Sheng Za Zhi. 1998;17:226-41.

82. Wang WW, Yang WM, Zhang YX, Zhao SY, Research on the relationship of the susceptibility to elderly gastric cancer and GSTM1 gene polymorphism in Hainan. Xian Dai Yu Fang Yi Xue. 2012;39:6273-4.

83. Wideroff L, Vaughan TL, Farin FM, Gammon MD, Risch H, Stanford JL, Chow WH. GST, NAT1, CYP1A1 polymorphisms and risk of esophageal and gastric adenocarcinomas. Cancer Detect Prev. 2007;31:233-6.

84. Wu MS, Chen CJ, Lin MT, Wang HP, Shun CT, Sheu JC, Lin JT. Genetic polymorphisms of cytochrome p450 2E1, glutathione S-transferase M1 and T1, and susceptibility to gastric carcinoma in Taiwan. Int J Colorectal Dis. 2002;17:338-43.

85. Yadav DS, Devi TR, Ihsan R, Mishra AK, Kaushal M, Chauhan PS, et al Polymorphisms of glutathione-S-transferase genes and the risk of aero digestive tract cancers in the Northeast Indian population. Genet Test Mol Biomarkers 2010;14:715-23.

86. Yadav D, et al. Glutathione-S-transferase M1 and T1 genes and gastric cancer: a case control study in North Indian population. Gene. 2011;487:166-9.

87. Zendehdel K, Bahmanyar S, McCarthy S, Nyren O, Andersson B, Ye W. Genetic polymorphisms of glutathione S-transferase genes GSTP1, GSTM1, and GSTT1 and risk of esophageal and gastric cardia cancers. Cancer Causes Control. 2009;20:2031-8.

88. Zhang AP, Liu BH, Wang L, Gao Y, Li F, Sun SX: Glutathione S-transferase gene polymorphisms and risk of gastric cancer in a Chinese population. Asian Pac J Cancer Prev. 2011;12:3421-5.

89. Zhang X-L, Cui Y-H. GSTM1 null genotype and gastric cancer risk in the Chinese population: an updated meta-analysis and review. OncoTargets and therapy. $2015 ; 8: 969-75$.

90. Zhang YC, Deng CS, Zhou Y, Zhu YQ. Association of glutathione S-transferase M1 and T1 genetic polymorphisms with Helicobacter pylori infection and gastric adenocarcinoma. Shi Jie Hua Ren Xiao Hua Za Zhi. 2003;11:1306-9.

91. Zhanga Z, Fud G, Wanga M, Tongc N, Wangb S, Zhanga Z. P53 codon 72 polymorphism and ovarian cancer risk: a meta-analysis. Journal of Nanjing Medica University. 2008;22;279-85

92. Zhao Y, Deng X, Song G, Qin S, Liu Z. The GSTM1 Null Genotype Increased Risk of Gastric Cancer: A Meta-Analysis Based on 46 Studies. PLoS One. 2013;8:e81403.

93. Zheng ZL CYP2E1, GSTM1, GSTT1 polymorphisms and susceptibilities to cardia and non-cardia gastric cancer in high-risk area of China, The Master Thesis of Fujian Medical University. 2003.

94. Zheng TR, Zheng QH, Gong FS, Xie YQ, Wang XR. Gene deletion polymorphisms of GSTT1 and GSTM1 and susceptibility to stomach neoplasm. Shi Yong Zhong Liu Za Zhi. 2002;17:155-7.

95. Zhou Q, Zheng ZY, Wang LD, et al. Prevalence of genetic polymorphisms of GSTM1, GSTT1 and GSTP1 in subjects with gastric cardia adenocarcinoma at Linzhou, Henan. Zheng Zhou Da Xue Xue Bao (Yi Xue Ban). 2003;38:327-9.

96. Zhou T, Fan W, Han W, et al. The study of the association of GSTM1 gene polymorphism with susceptibility to gastric cancer. Chin J Curr Adv Gen Surg. 2006;9:355-8.

97. Zhu Y, He Q, Wang J, Pan HF. The association between GSTM1 polymorphism and gastric cancer risk: a meta-analysis. Mol Biol Rep. 2012;39:685-91. 